Supplement of Saf. Nucl. Waste Disposal, 1, 27-28, 2021

https://doi.org/10.5194/sand-1-27-2021-supplement

(c) Author(s) 2021. CC BY 4.0 License.

(c) (1)

Supplement of

\title{
LD-SAFE: laser dismantling environmental and safety assessment
}

Damien Roulet et al.

Correspondence to: Damien Roulet (droulet@onet.fr) and Pierre Daguin (pdaguin@ onet.fr)

The copyright of individual parts of the supplement might differ from the article licence. 

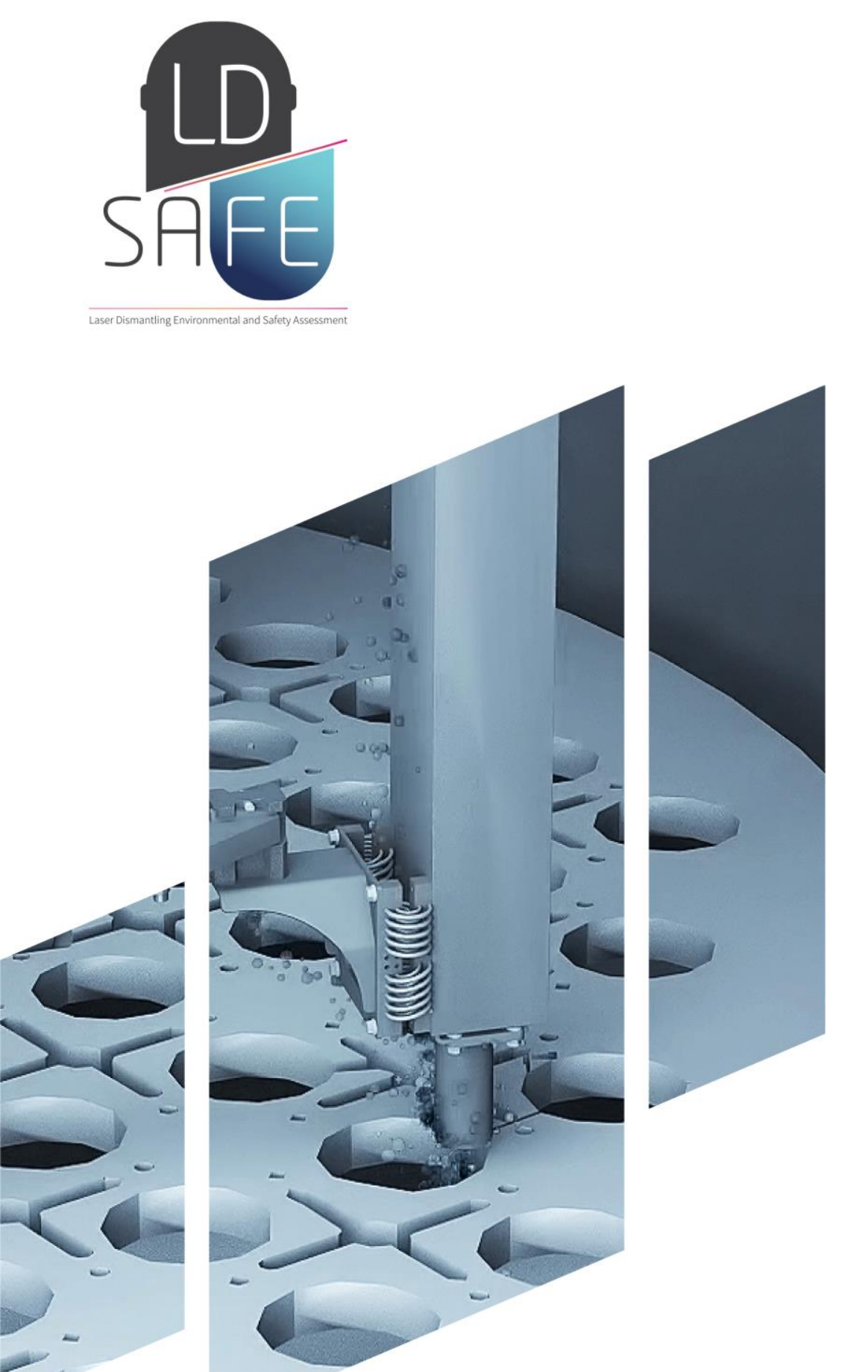

OกЕT E теспато

IRSN vysusGroup FEOUANS

\section{LD-SAFE \\ BASE symposium (safeND) \\ Project presentation}

Author: ONET TECHNOLOGIES

Date: Nov. 12, 2021

This project has received funding from the Euratom research and training programme 2019-2020 under grant agreement No 945255 


\section{LD-SAFE Summary}

\section{CONTENT}

1. INTRODUCTION

2. CUTTING TECHNIQUES

3. LASER CUTTING

4. LD-SAFE

5. SAFETY ASPECTS

6. CONCLUSION 


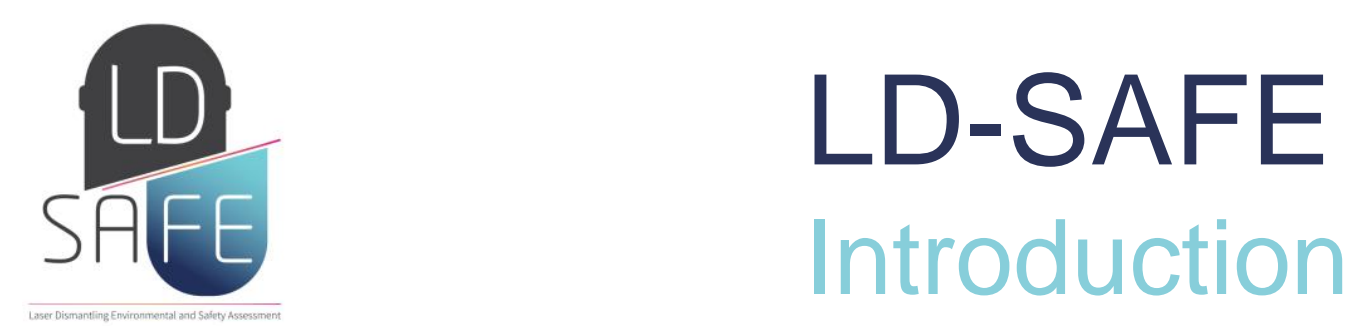

\section{Decommissioning of a power reactor}

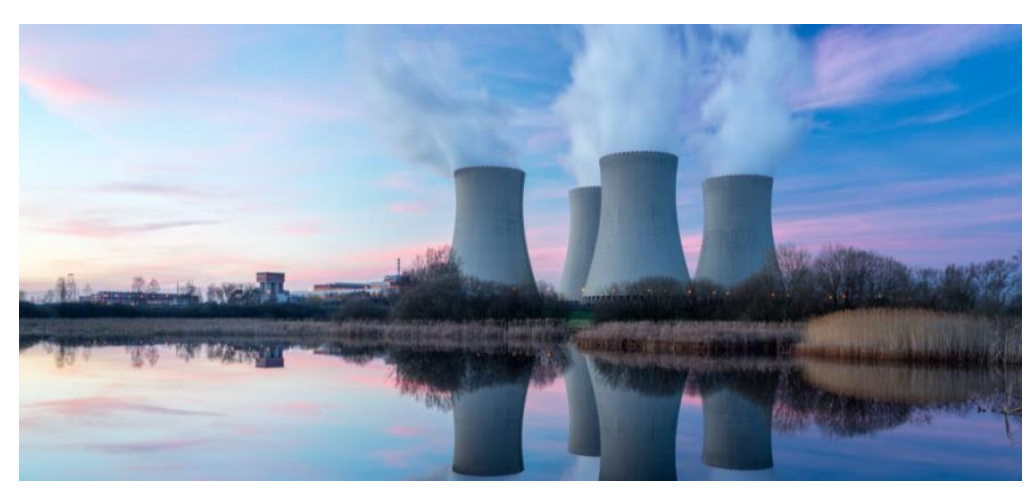

- Commonly scheduled to be completed over a long period (over 20 years for PUR/BWR in general)

- Change in strategy (immediate dismantling after permanent shutdown)

- New challenges (acceleration of the decommissioning project schedules)

- Meed to improve the dismantling processes and existing techniques

D Key operation to improve: cutting of Reactor Pressure Vessel and Internals 


\section{LD-SAFE \\ Cutting techniques}

\section{main categories / main tools used}

- Thermal cutting (Plasma Arc Cutting)

- Thechanical cutting (Band Saw Cutting)

- Hydraulic cutting (Abrasive Water Jet Cutting)

\section{Comparison / Limitations}

\section{Plasma Arc cutting}

Large dimensions

Fast

Less maintenance on site

High degree of filtration

Slower underwater

Electrically conductive material

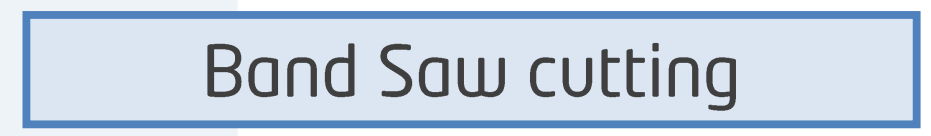

Cut large thicknesses

All materials

timited contamination

Slow (cutting speed)

maintenance

Wear part replacement

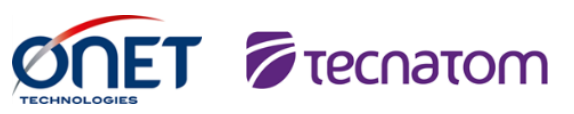

IRSN VysusGroup F EOUANS

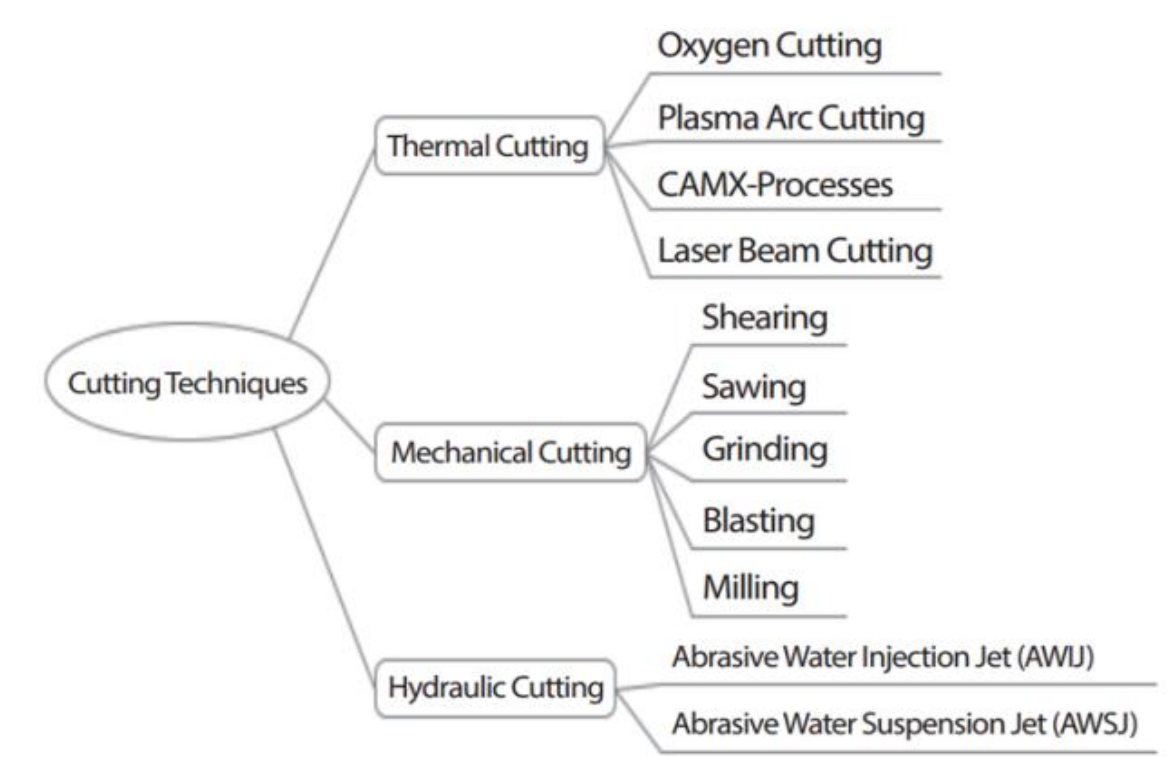

Classification of remote handling technologies

Abrasive Water Jet cutting

Complicated shape

All materials

Few air pollution

Advantages

Water treatment

High cost

Drawbacks

Required space 


\section{LD-SAFE \\ Cutting techniques

\section{need}

- Development of innovative technologies

- Improve safety, radiation protection, waste management, time and cost aspects

\section{Why adapting laser cutting technology for RPV and RVI?}

- Key benefits in comparison with conventional cutting techniques

- More than 10 years of R\&D (laboratory testing)

- mature and operational technology for dismantling activities (already used for fuel cycle / research facilities)

\section{Examples of operational experience}

- Dissolvers of UP1 mAR200 fuel reprocessing facility at CEA in France

- Piping at Creys-Talville MPP (SUPERPHEnIX prototype fast reactor)

- Radioactive waste evaporator at La Hague site 


\section{LD LD-SAFE Laser culting \\ Key benefits for dismantling}

- Safe for the workers (remote operations)

- Time reduction and cost efficiency in operation

- Effortless cutting with high performance

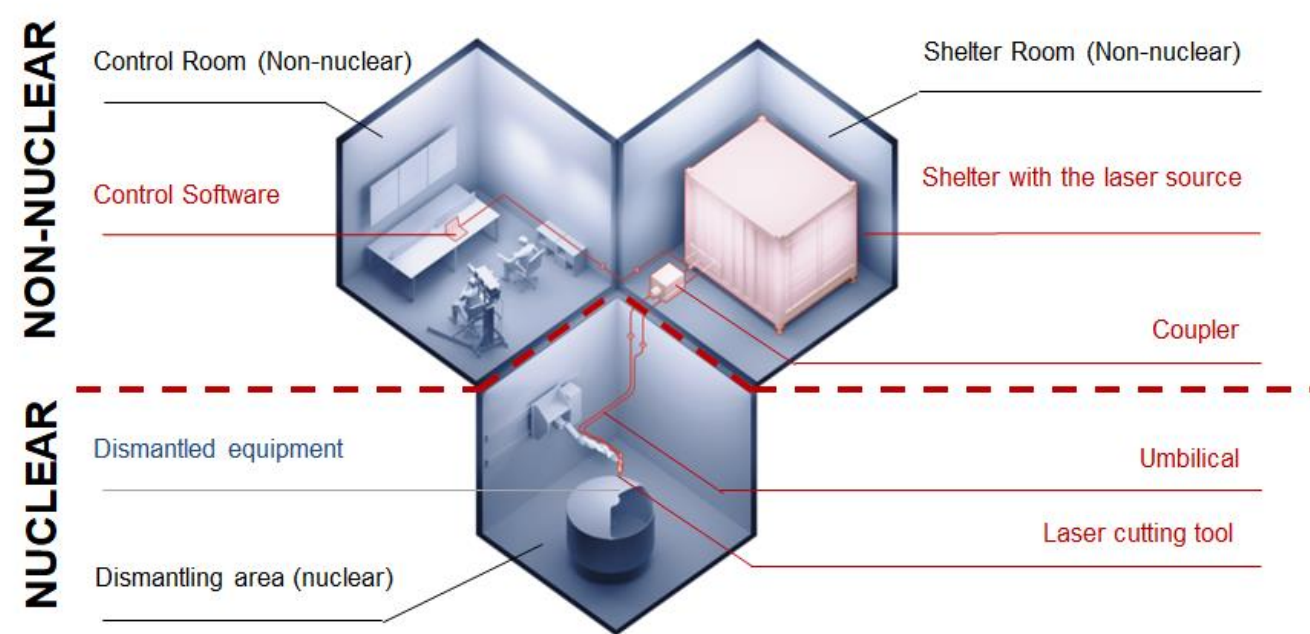

- Ability to cut complex geometries

- minimization of the secondary waste (aerosols and mass removed)

- Cleaner than most of other thermal techniques (especially for dust \& fumes)

- Robustness and reliability, no maintenance

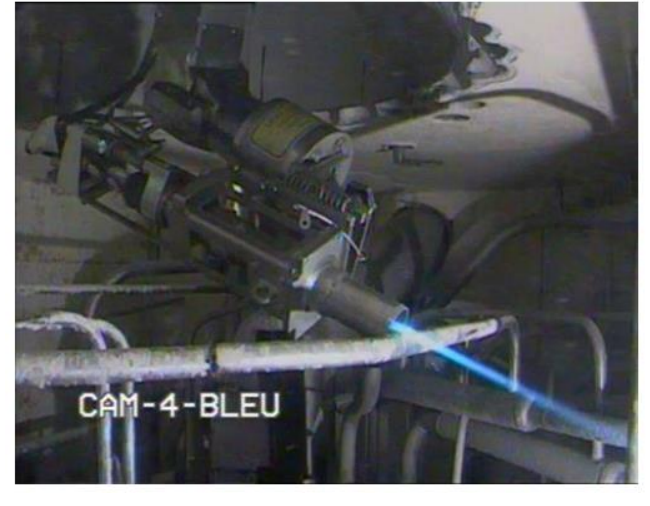

Up to $200 \mathrm{~mm}$ in thickness in air (14kW laser power)

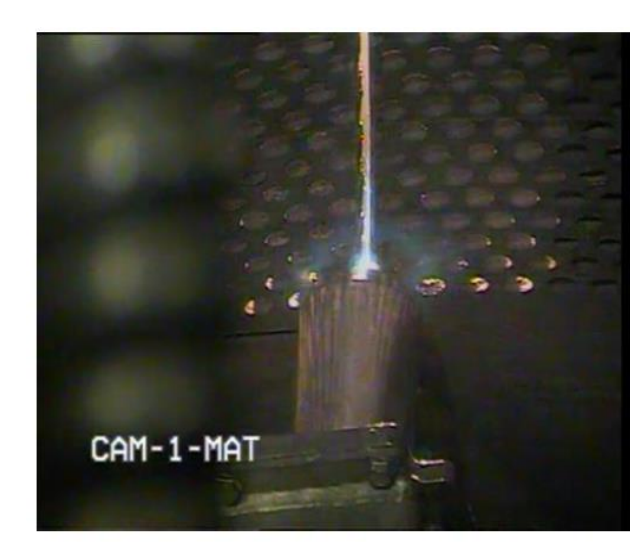
or wear parts in controlled area 


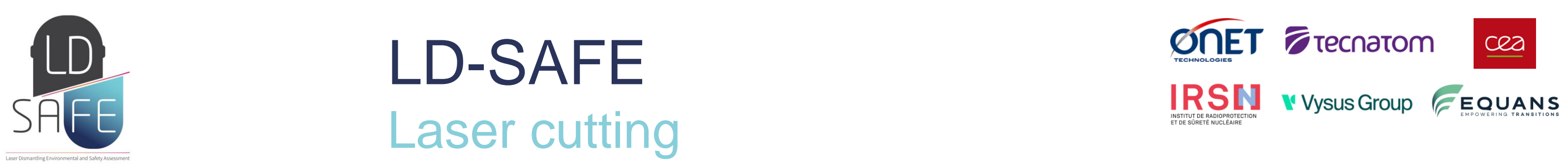

\section{not yet widely used in the nuclear decommissioning industry?}

- Laser considered as new technology (never used for power nuclear reactor dismantling)

- Compliance with safety requirements need to be checked

\section{most challenging task}

- Dismantling Reactor Pressure Vessels and Internals (RPV and RVI) of Power nuclear Reactor

\section{LD-SAFE (H2020 program)}

$>$ To promote the use of laser cutting technology for dismantling PUR and BUR (the most used in Europe)

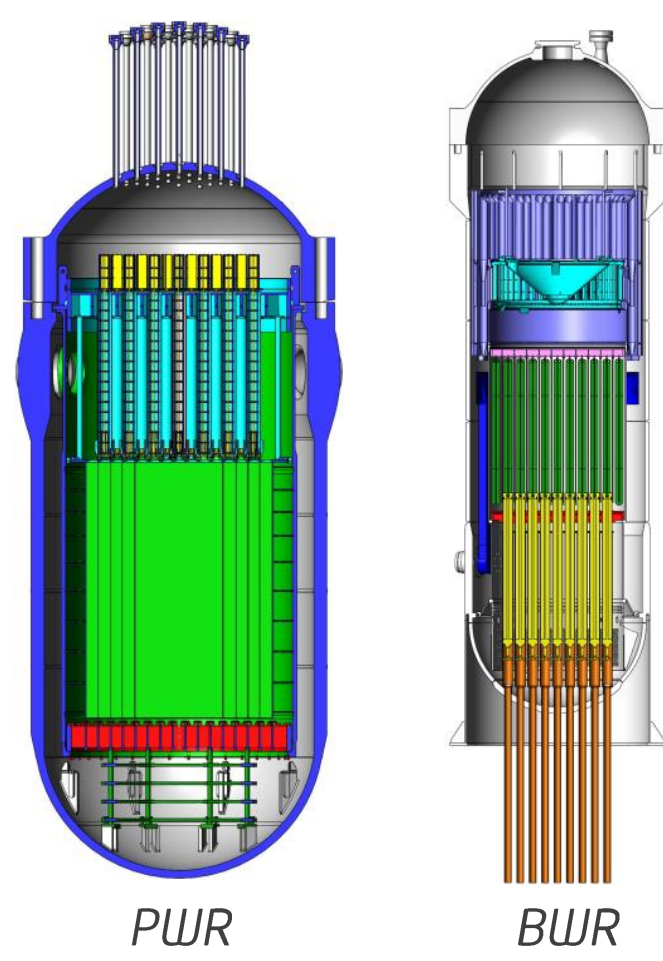




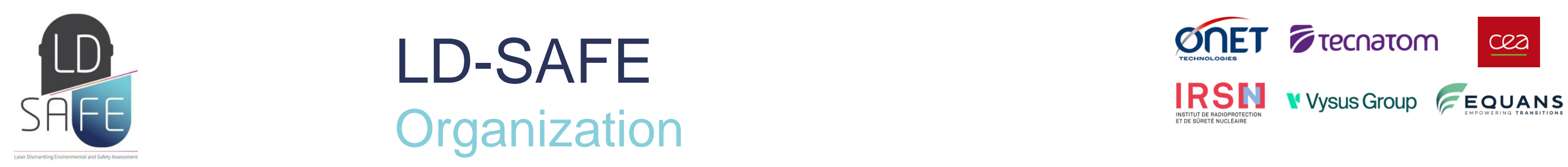

\section{H2020 program}

- R + D + i project

- Funding by EC (Euratom)

- 4 years (July 2020 to June 2024)

\section{Consortium}

\section{ONET TECHNOLOGIES - France}

EQUARS (ERGIE) - Belgium

CER - France

VYSUS GROUP - Sweden

IRSn - France

TECNATOM - Spain

\section{Overall organization}

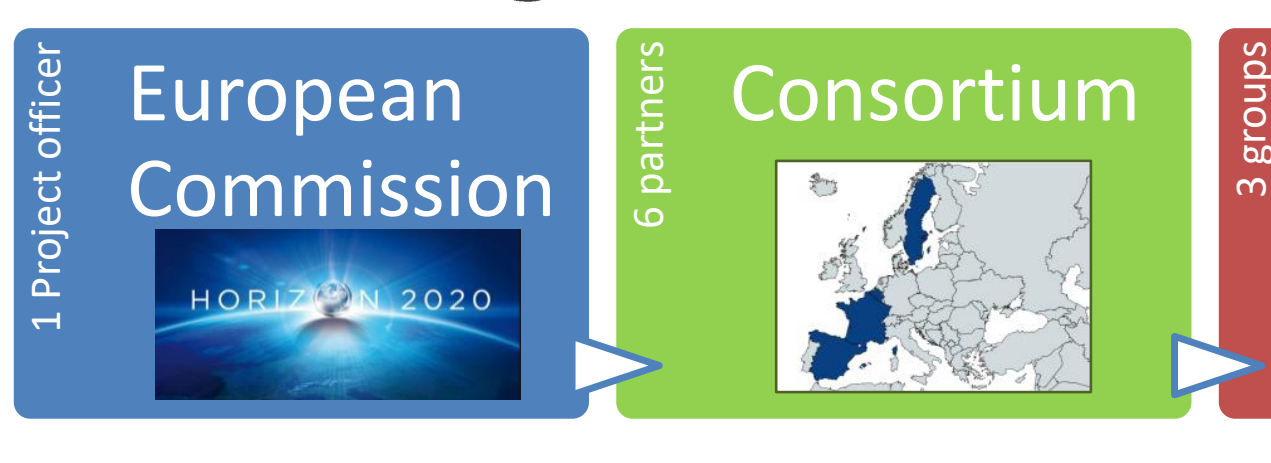

End

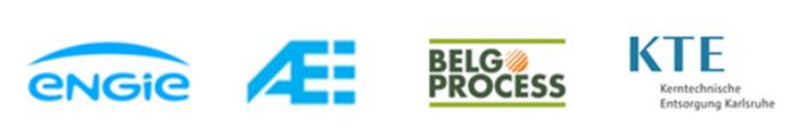

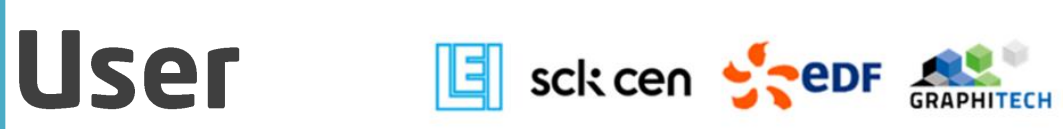

GrOUP (बAEA) BEL $V$ Y SOGIN ODounreay

SUPport JEPIC EDा
Group 


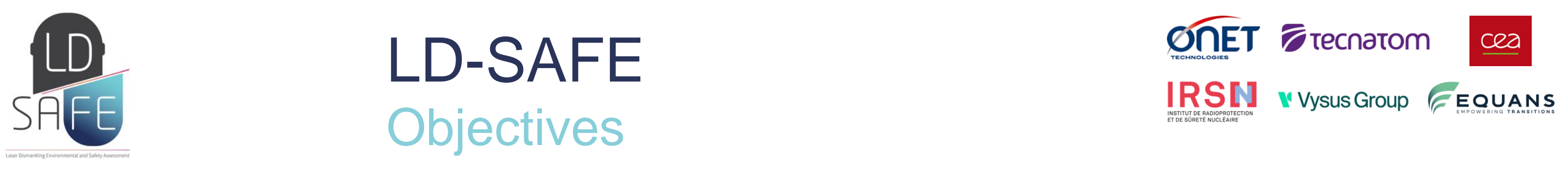

\section{main objectives}

To demonstrate in-air and underwater technical capabilities, safety, economic advantages and suitability for power nuclear reactor dismantling activities.

Objective 1: Demonstration of the capabilities of a versatile laser cutting solution to address key technical challenges in large ПPPs decommissioning.

Objective 2: Environmental and safety assessment of the implementation of laser cutting for nuclear reactor decommissioning.

Objective 3: Technical validation of the laser cutting prototype in operational environment.

Objective 4: Demonstration of the economic advantage of using laser cutting technology for the forthcoming reactor decommissioning market.

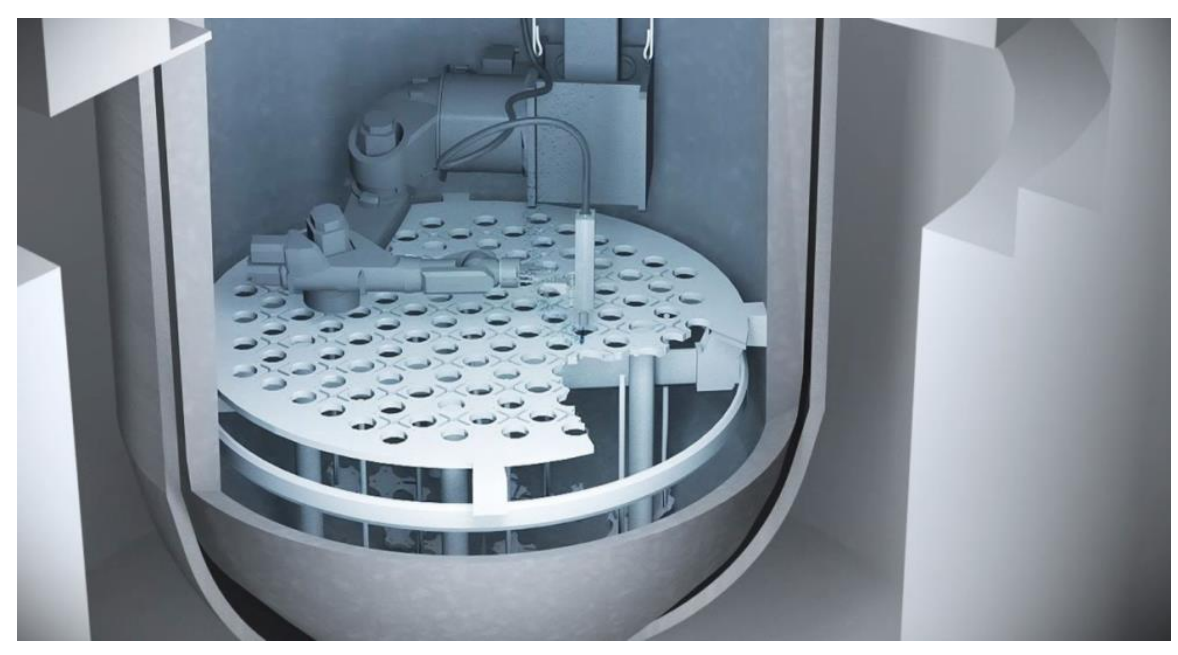




\section{LD-SAFE Concept

\section{LD-SAFE project}

Laser cutting to replace conventional cutting techniques for the dismantling of commercial reactor components

\section{Advantages of cutting laser technology}

Effortless cutting and excellent cutting performances Easily automatized with a manipulator in remote operation Minimization of the secondary waste produced Safe for the operation and maintenance workers
Modular system Easily installed in existing facilities

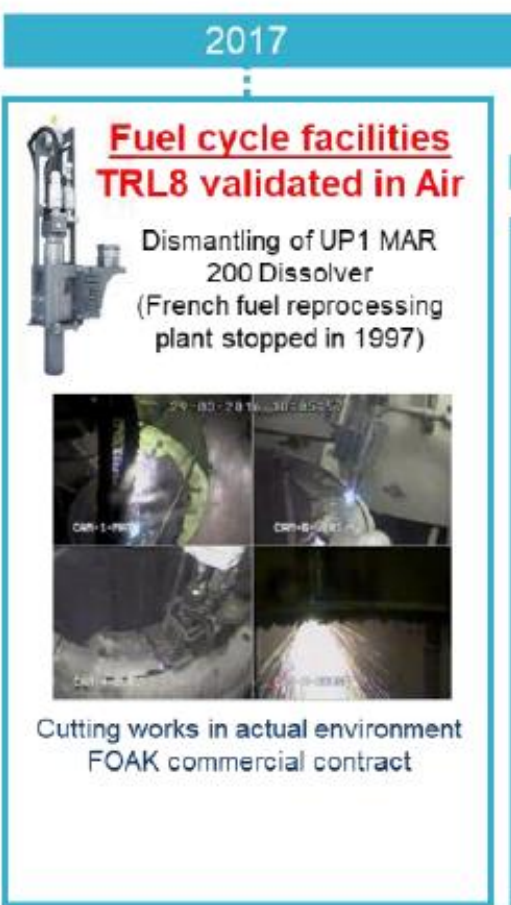

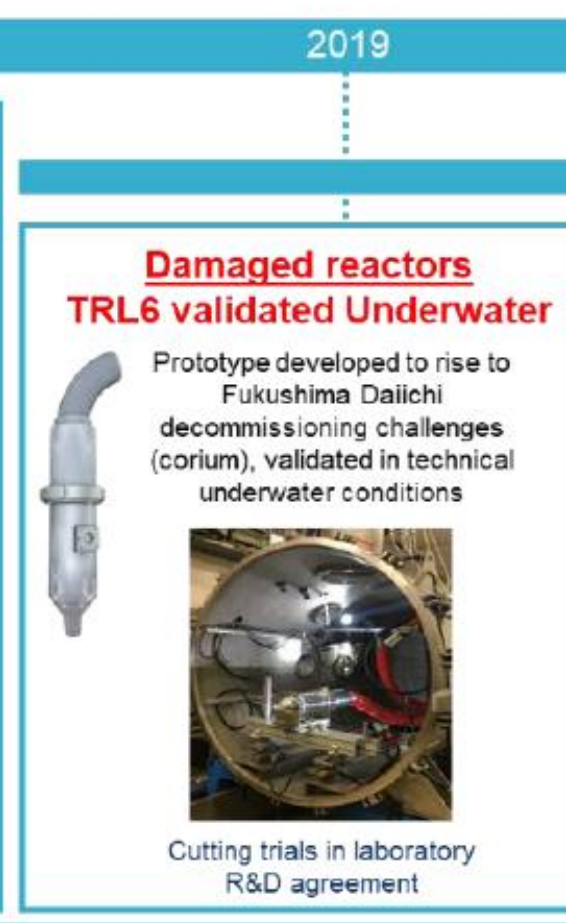

Nuclear power reactors TRL6 in Air \& TRL5 Underwater

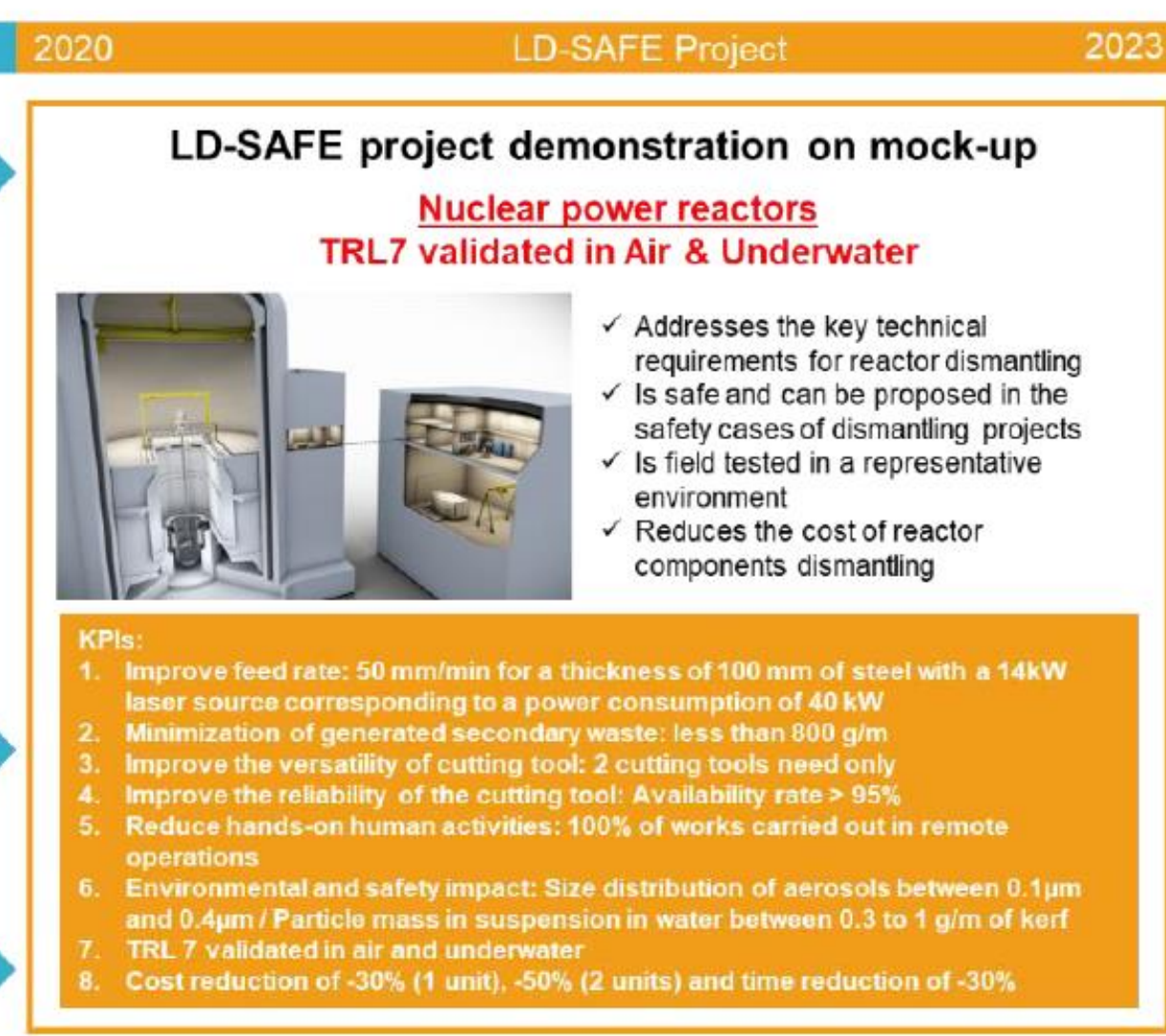




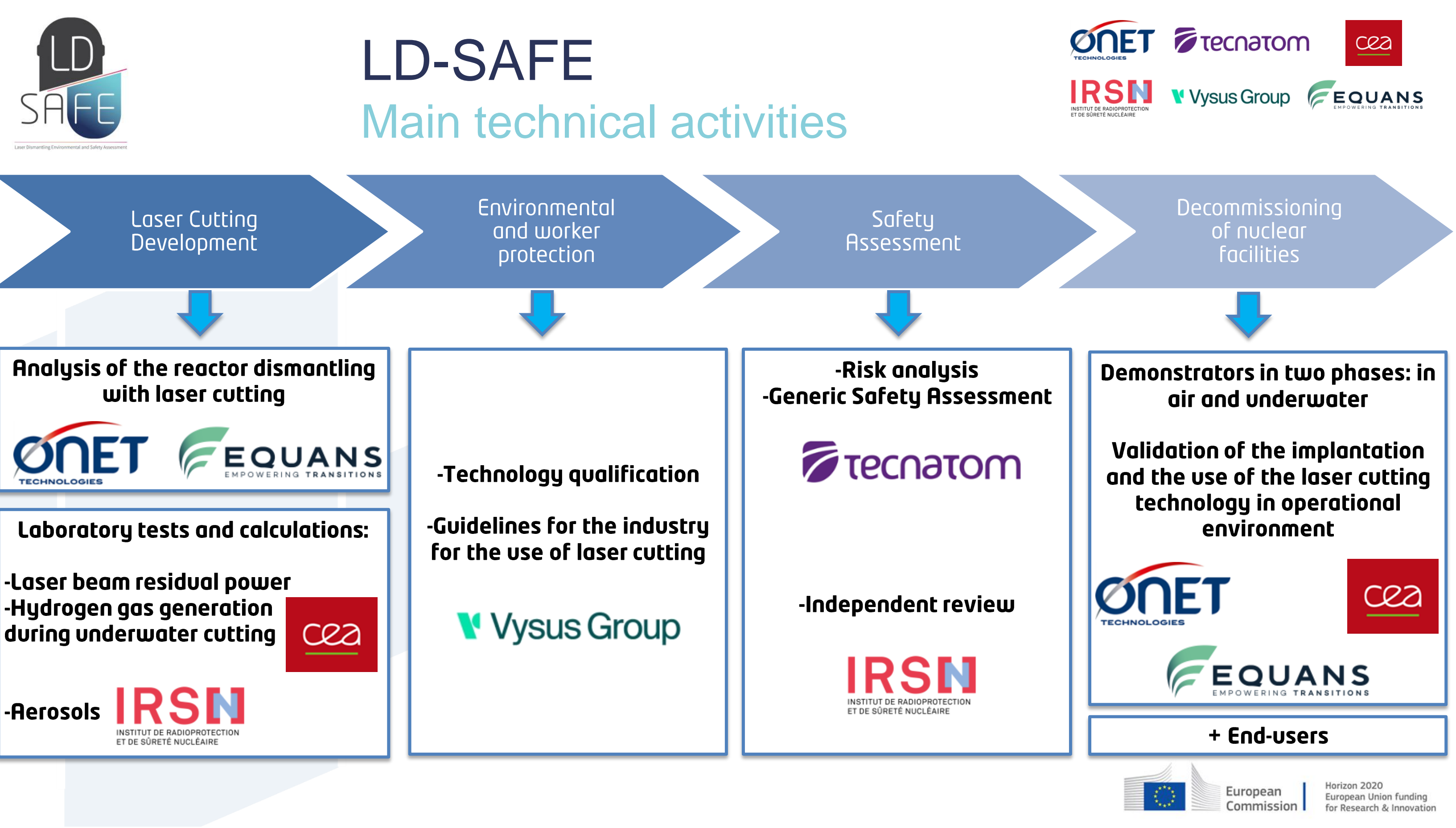




\section{LD-SAFE Safety aspects}

\section{Preliminary risk analysis performed}

- Identifying and evaluating radiological and conventional risks,

- Identifying safety systems, measures and controls,

- Identifying uncertainties.

Risk Analysis (preliminary)

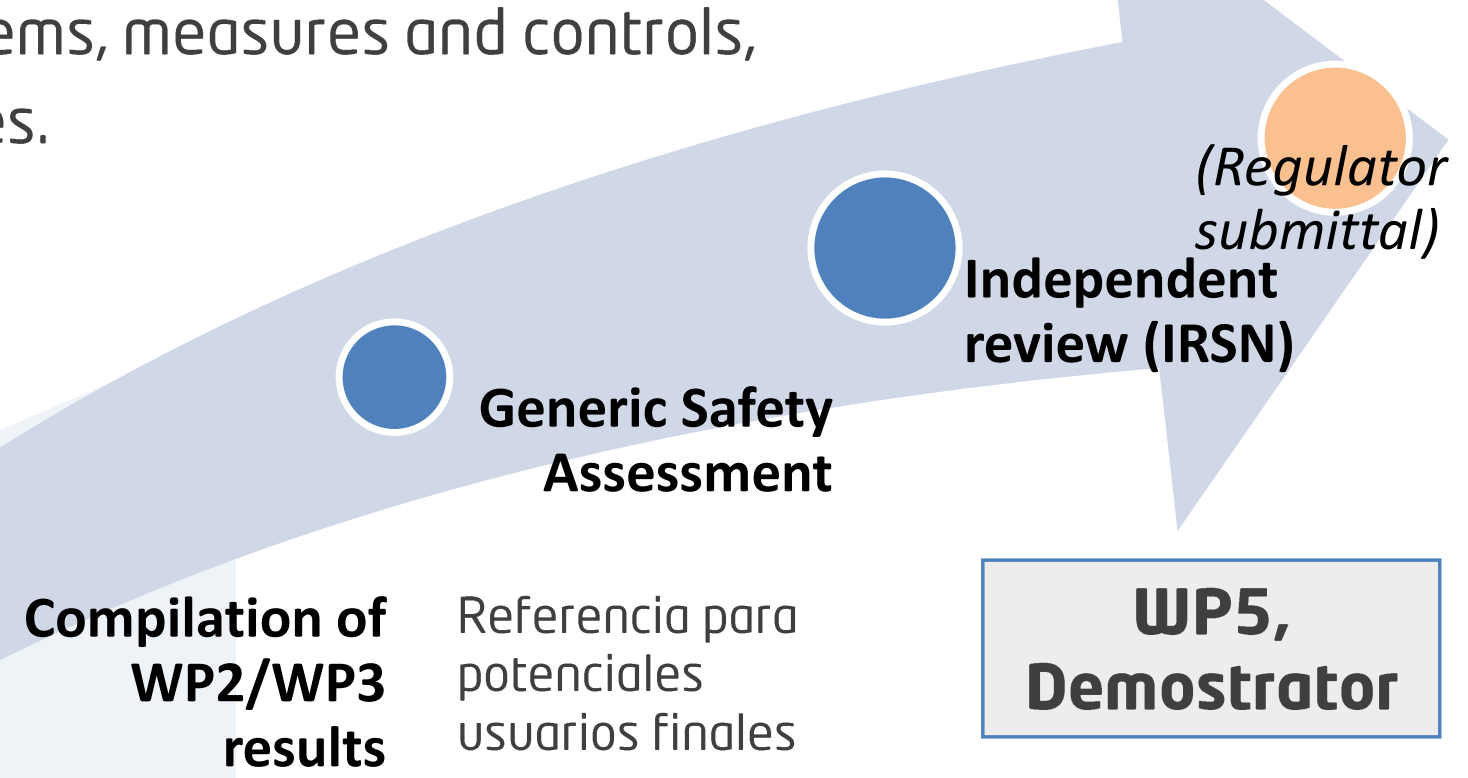

- UP2, Laboratory Tests : $\mathrm{H}_{2}$ and aerosols generation, and residual laser beam power

$\longrightarrow$. WP3, Workers and environment protection

Safety Reports Series

N 0.77

(G) IAEA

Safety Assessment for Decommissioning

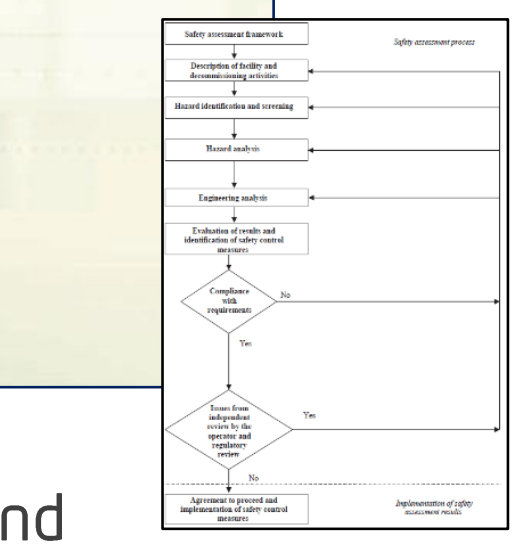




\section{Risk matrixes for normal and Accident Conditions - "Safety Envelope"}

normal segmentation conditions

\begin{tabular}{|c|c|c|c|c|c|c|c|}
\hline \multirow[b]{2}{*}{ Situation } & \multirow[b]{2}{*}{$\begin{array}{l}\text { Associated } \\
\text { Activities }\end{array}$} & \multirow[b]{2}{*}{ Potentiol Couses } & \multicolumn{4}{|c|}{ Unoptimized Conditions } & \multirow{2}{*}{$\begin{array}{c}\text { Sofety meosures ond Controls } \\
\text { Design options }\end{array}$} \\
\hline & & & $\begin{array}{c}\text { Probability } \\
\text { (1) }\end{array}$ & Dose to Workers & Dose to Public & Environment & \\
\hline $\begin{array}{l}\text { External Exposure } \\
\text { Mormal conditions }\end{array}$ & All activities & $\begin{array}{l}\text { Activities in radiation and contominated } \\
\text { oreas. }\end{array}$ & $\begin{array}{c}\text { All along } \\
\text { the process }\end{array}$ & $\begin{array}{l}\text { Very high if no } \\
\text { measures ore token } \\
\text { due to highly } \\
\text { octivoted moteriols }\end{array}$ & \multirow[t]{2}{*}{ Low } & $\Pi / \mathrm{A}$ & $\begin{array}{l}\text { Remote Operation, robust design, easy instollation \& decontamination. } \\
\text { Shielding, dosimeters, ond other Radiation Protection (RP) procedures and } \\
\text { controls. } \\
\text { Areo Rodiation Monitoring. } \\
\text { Woter Level monitoring. } \\
\text { Building off-gas system monitoring and filtration. } \\
\text { Troining. }\end{array}$ \\
\hline $\begin{array}{l}\text { Internal Exposure } \\
\text { Пormal conditions }\end{array}$ & $\begin{array}{l}\text { Segmentation } \\
\text { activities }\end{array}$ & $\begin{array}{l}\text { Pirborne releoses during RPV/RVI cutting. } \\
\text { Sublimation of ruthenium to goseous form } \\
\text { (in-air cutting). }\end{array}$ & $\begin{array}{c}\text { All along } \\
\text { the process }\end{array}$ & Very low & & $\Pi / \mathrm{A}$ & $\begin{array}{l}\text { Remote Operation. } \\
\text { Dust/oerosols collection system. } \\
\text { Contomination Control Confinement (Airlock). } \\
\text { Area Radiation monitoring. } \\
\text { Building off-gos system monitoring and filtrotion. }\end{array}$ \\
\hline $\begin{array}{l}\text { Effluents ond } \\
\text { secondary woste } \\
\text { חormal conditions }\end{array}$ & $\begin{array}{l}\text { Segmentation } \\
\text { octivities }\end{array}$ & $\begin{array}{l}\text { Airborne releases, dross generotion, and } \\
\text { woter contamination during RPV/RVI cutting. }\end{array}$ & $\begin{array}{c}\text { All along } \\
\text { the process }\end{array}$ & $\Pi / \mathrm{H}$ & $\Gamma / \mathrm{H}$ & Very Low & $\begin{array}{l}\text { Protection of covity floor. } \\
\text { Effluents Monitoring. } \\
\text { Auxiliory water filtrotion systems. }\end{array}$ \\
\hline $\begin{array}{l}\text { Waste management } \\
\text { Пormal conditions }\end{array}$ & $\begin{array}{l}\text { Radioactive woste } \\
\text { hondling and fluxes }\end{array}$ & Cutting pottern choice & $\begin{array}{c}\text { All along } \\
\text { the process }\end{array}$ & Very low & $\Gamma / \mathrm{H}$ & $\Pi / \beta$ & $\begin{array}{l}\text { Minimize woste generation. } \\
\text { Shielding. } \\
\text { Online removal of waste. } \\
\text { Optimization of woste location considering personnel walking paths. }\end{array}$ \\
\hline $\begin{array}{l}\text { Hozardous materials } \\
\text { exposure } \\
\text { Mormal conditions }\end{array}$ & $\begin{array}{l}\text { Segmentation } \\
\text { octivities }\end{array}$ & $\begin{array}{l}\text { Potentiol generotion of hozardous chemical } \\
\text { compounds during cutting operotions, such } \\
\text { os ozone, carbon oxides, nickel carbonyl. } \\
\text { nitrogen oxide ond toluene. } \\
\text { Hexovalent chromium generation during } \\
\text { stainless steel cutting. }\end{array}$ & $\begin{array}{c}\text { All along } \\
\text { the process }\end{array}$ & $\Pi / \mathrm{H}$ & $\Gamma / \mathrm{H}$ & Toxicity & $\begin{array}{l}\text { Dust/oerosols collection system. } \\
\text { Contamination Control Confinement (Airlock). } \\
\text { Area Rodiation Monitoring. }\end{array}$ \\
\hline $\begin{array}{l}\text { Maintenance } \\
\text { operation } \\
\text { Mormal conditions }\end{array}$ & $\begin{array}{l}\text { Thaintenonce (nozzle } \\
\text { replocement, } \\
\text { support equipment - } \\
\text { platform-... }\end{array}$ & $\begin{array}{l}\text { Maintenance activities, repairs, and } \\
\text { replocements. }\end{array}$ & $\begin{array}{c}\text { All along } \\
\text { the process }\end{array}$ & Low & $\Gamma / \mathrm{A}$ & $\Pi / \mathrm{H}$ & $\begin{array}{l}\text { Robust design eosy and scarce mointenance. } \\
\text { RP procedures ond controls. } \\
\text { Protective personal equipment. }\end{array}$ \\
\hline
\end{tabular}




\section{LD-SAFE Safety aspects}

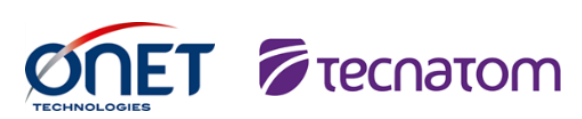

IRSE]

Vysus Group

F EOUANS

- WP2. Tests and calculations of hydrogen and aerosols generation, and of residual laser beam power (performed in DELIA Facility at CEA Saclay).

- WP3. System maturity and integration analysis.

- WP5. Demonstration of laser cutting technology safety and efficiency in mock-up (reactor components and conditions simulation).
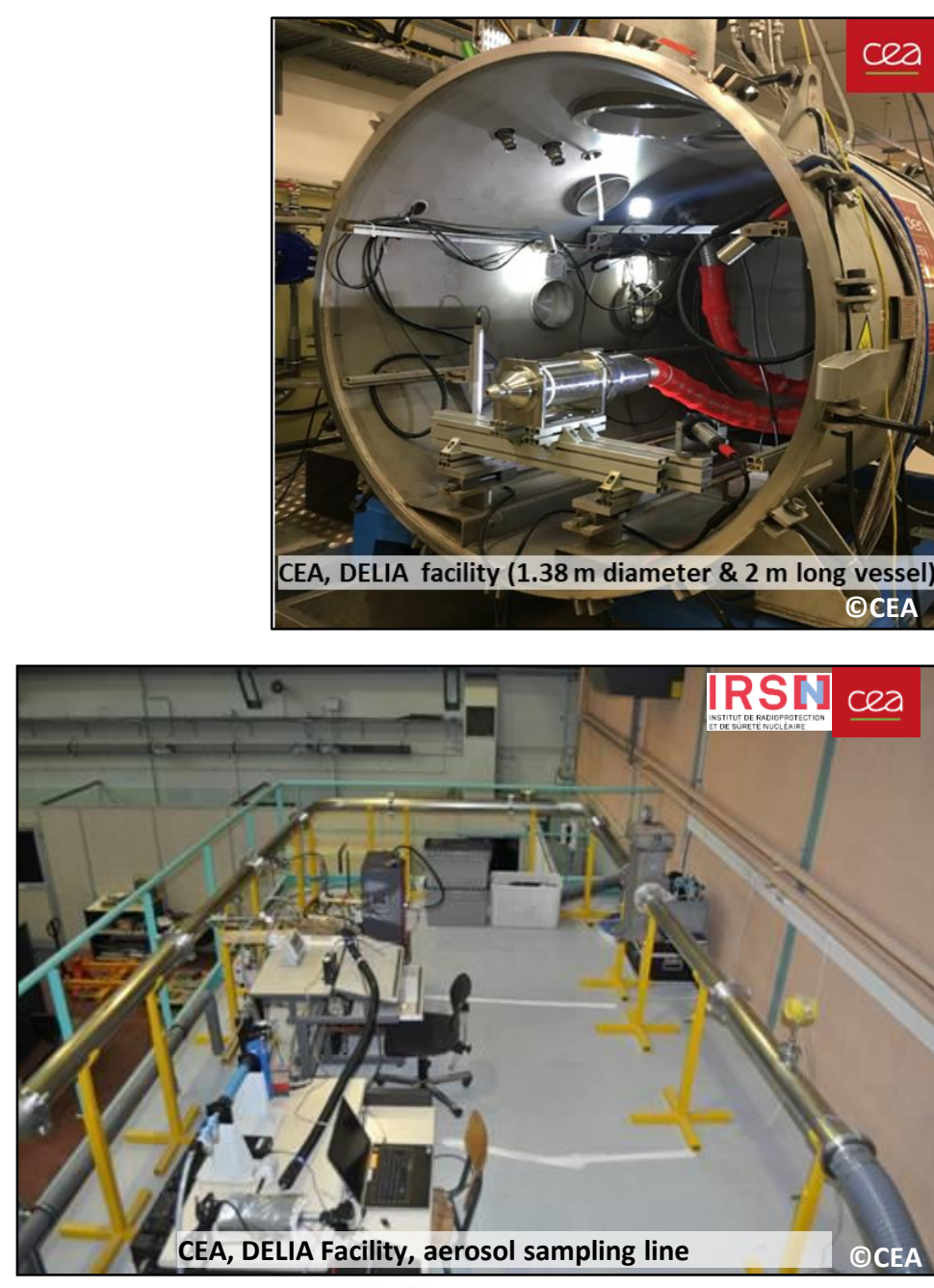


\section{LD-SAFE Conclusion

\section{Expected impact}

-To support the European industry by enhancing the decommissioning sector based on EU safety culture and knowhow.

-To propose an innovation (in terms of safety, economic and technical aspects)

Dlmproving the segmentation of RPV/RVI

Achieving a world first laser dismantling of a power nuclear reactor!

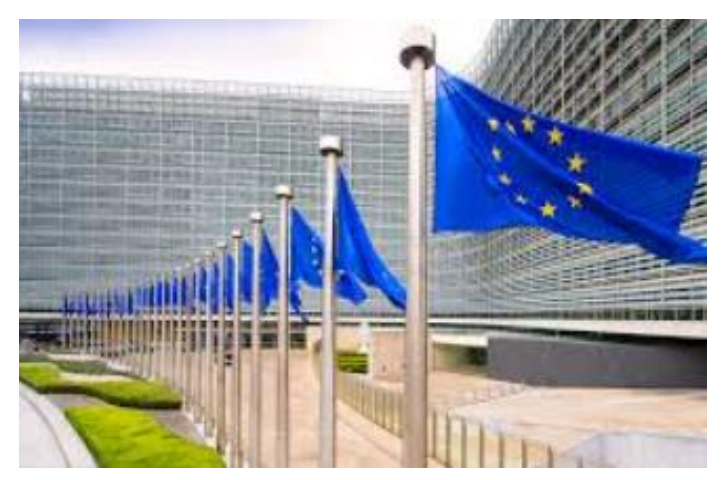




\section{Thank you!}

\section{Q\&A}

\section{Upcoming events}

- UnE 2021 - LD-SAFE workshop public session Dec. 1, 2021 - Paris, France
Follow us

(D) https://ldsafe.eu/

Linked in. LD-SAFE Project

@ld_safe 